\title{
Explaining the reception of the Code Napoleon in Germany: a fuzzy-set qualitative comparative analysis*
}

\author{
TT Arvind and Lindsay Stirton \\ York Law School, University of York; School of Law, University of Manchester
}

This paper examines the diverse responses of the German states to the Code Napoleon at the beginning of the nineteenth century. These states differed both in the extent to which they adopted the Code, and the extent to which they retained the Code after Napoleon's influence waned. In order to identify the causes of adoption and retention of the Code, we use fuzzy-set qualitative comparative analysis ( $\left.f_{s} Q C A\right)$. This method is now well established in comparative research in the social sciences but has been little used in comparative legal analysis. We find the following to be among the conditions relevant to the reception of the Code: territorial diversity, control by Napoleon, central state institutions, a feudal economy and society, liberal (enlightented absolutist) rule, nativism among the governing elites and popular anti-French sentiment. The paper also serves to demonstrate the potential of $f_{S} Q C A$ as a method for comparative lawyers.

An important part of Napoleon's agenda for Germany was the modernisation of its legal system through the reception of the Code Napoleon. However, the responses of the German states to Napoleon's demands were diverse. Some (such as Bavaria and Württemberg) considered the adoption of the Code, but rejected the idea. Others (including Nassau and Hesse) announced its adoption, but never brought it into effect. A number of states adopted the Code either as it was (eg Westphalia and AnhaltKöthen) or with modifications (eg Frankfurt), only to abandon it after Napoleon was defeated. Still others adopted the Code either with modifications (as in the case of Baden) or without modification (as in the case of Berg), and retained it even after Napoleon's defeat.

The purpose of this paper is to explain these diverse responses to the question of adopting the Code. The question has never been satisfactorily answered, despite a vast literature about the spread of the Code during the Napoleonic period. A number of authors focus on a single factor in their explanations, such as the strength of anti-establishment forces opposed to entrenched class interests, ${ }^{1}$ nationalistic

* Winner of the SLS Best Paper Prize 2009. Earlier versions of this paper were presented at departmental seminars in York and Manchester. We would like to thank the participants at these sessions and to the following individuals for encouragement and sometimes critical suggestions: Oscar Alvarez-Macotela, John Bell, Jurgen De Wispelaere, Stefan Enchelmeier, Paula Giliker, William Lucy, Hisako Nomura, Mathias Siems and Jenny Steele. For the remaining errors and omissions, each co-author blames the other.

1. RC van Caenegem Judges, Legislators and Professors: Chapters in European Legal History Goodhart Lectures 1984-1985 (Cambridge: Cambridge University Press, 1987) pp 48-50 and 152-155. 


\section{Legal Studies, Vol. 30 No. 1}

sentiment, ${ }^{2}$ loyalty to the pre-Napoleonic state and order, ${ }^{3}$ the degree of control over the state by Napoleon, ${ }^{4}$ opposition to the Code's radical provisions on gender, familial and sexual relations, ${ }^{5}$ and attachment to the established customs and traditions of a state. ${ }^{6}$ Focusing on a single factor, however, neglects the causal complexity behind the adoption and retention of the Code: it is implausible that a single factor was dispositive, or that every factor identified in each of these works was present in the same strength in all cases of adoption and absent in all cases of non-adoption. A few modern commentators have recognised this. Weinacht suggests a complex mix of factors to explain why some German states adopted the Code while others did not. Central to his explanation is a diverse coalition of feudal, dynastic, conservative and nationalistic groups, each of which was protecting its own interests and wielded a different degree of power in different states. ${ }^{7}$ Similarly, Fehrenbach, in her study of the reception of the Code in the states of the Confederation of the Rhine, focuses on the complexity of issues involved. She discusses the problems of feudal property relations, the need to introduce constitutions for the individual states to replace the defunct constitution of the Holy Roman Empire, the restructuring of administration on French principles and the perceived liberal-commercial base of the Code. ${ }^{8}$ Neither study, however, gives a full account of the interplay between these factors, despite acknowledging that no one of them was on its own dispositive, nor do they discuss how these factors related to the decision to retain or abandon the Code.

This question is of more than historical interest. Debates about codification continue to provoke controversy, as evidenced by the discussion surrounding present-day attempts to draft codes or principles on various aspects of European private law. Like the Code Napoleon, these are intended to reflect transnational principles and, ultimately, to form the base of a unified European legal system. The diverse reactions to an earlier attempt to produce such a code, and the circumstances that produced those reactions, hold lessons for the present. In addition, in the last few years a significant body of literature has emerged which suggests that patterns of economic development can, in part, be explained by the legal families to which different countries belong. The proponents of this 'legal origins theory' claim that countries with French legal origins are likely to be less economically developed than countries with English, German or Scandinavian legal origins, other things being equal. The reason for this, they argue, lies in the fact that the Code Napoleon is, for historical reasons, oriented towards state

2. T Krebs Restitution at the Crossroads: A Comparative Study (London: Routledge Cavendish, 2001) p 15.

3. JH Merryman 'The French deviation' (1996) 44 American Journal of Comparative Law 109.

4. H Blackenburg 'The extension of the Code Napoleon into Germany', $\mathrm{PhD}$ thesis (University of Wisconsin, 1931).

5. IV Hull Sexuality, State and Civil Society in Germany: 1700-1815 (Cornell: Cornell University Press, 1997) pp 372-402.

6. MB Crosby The Making of a German Constitution: A Slow Revolution (Oxford: Berg Publishers, 2008) pp 68-71.

7. P-L Weinacht 'The sovereign German states and the Code Napoléon: what spoke for its adoption in the Rhine Confederation?' (2002) 14 European Journal of Law and Economics 205 at 210 .

8. E Fehrenbach Der Kampf um die Einführung des Code Napoleon in den Rheinbundstaaten Institut für Europäische Geschichte Mainz Vorträge Nr 56 (Wiesbaden: Franz Steiner Verlag, 1973) pp 7-39. 
control and therefore less friendly to modern commerce. ${ }^{9}$ By analysing the factors that influenced the German states' adoption of the Code Napoleon, we can examine whether their claims have historical support. For example, if the key difference between the approach of the common law and the Code Napoleon lay in the independence of the judiciary, the common law's regard for private property and contract and its support for judicial law making and adaptation, as the theorists claim, one would expect to see a preference for the absence of these factors in countries which adopted the Code. If such preferences are absent, the causes of the 'legal origins effect' are likely to lie elsewhere.

So is it possible to arrive at an understanding as to which factors were actually operative on the decision to adopt or reject the Code? In this paper, we approach this question using fuzzy-set qualitative comparative analysis (fsQCA), a method that, while established in the social sciences, is new to law. The question we ask - and answer - is of interest in itself. However, in addition, we seek to use the question of the Code Napoleon to showcase this method and demonstrate its power as a tool to assist research into questions of this type, which are of interest to comparative lawyers and regularly asked in comparative law research.

\section{BACKGROUND: THE PROBLEM OF THE CODE NAPOLEON}

Napoleon's invasion radically transformed Germany. The number, nature and boundaries of its constituent states were dramatically changed. Portions of Germany were annexed by France, and the Holy Roman Empire and its institutions were brought to a sudden end. ${ }^{10}$ This created obvious constitutional questions, and also posed issues of legitimacy for rulers who found themselves ruling territories whose subjects had no traditional loyalty to their new states or their ruling houses and who were not infrequently hostile. ${ }^{11}$ Over and above this, the surviving German states came under pressure from Napoleon to modernise their legal systems and society as part of Napoleon's broader agenda for Europe.

This came at a general time of social and political change in Germany. The German Enlightenment, the Aufklärung, had created a variety of liberal tendencies in Germany, as a result of which there were existing reform movements in Germany. ${ }^{12}$ This was accentuated by the proto-industrialisation ${ }^{13}$ and mercantalisation of the economy of many German states, which created a new set of rising classes in the form of the rural craftsmen and the urban merchants and entrepreneurs, whose activities collectively challenged the old elite represented by the guilds and the old middle classes. ${ }^{14}$ German states had therefore begun to be faced with the issue of administrative and legal reform even before the Napoleonic period.

9. For a review of this literature by some of its main contributors, see R La Porta, FL de Silanes and A Shleiffer 'The economic consequences of legal origins' (2008) 46 Journal of Economic Literature 285.

10. A Grab Napoleon and the Transformation of Europe European History in Perspective (Basingstoke: Palgrave Macmillan, 2003) pp 88-92.

11. D Blackbourn The Long Nineteenth Century (London: Fontana Press, 1997) pp 75-78.

12. FC Beiser Enlightenment, Revolution, and Romanticism: The Genesis of Modern German Political Thought, 1790-1800 (Cambridge, MA: Harvard University Press, 1992) pp 13-26.

13. SC Ogilvie 'Proto-industrialization in Germany' in SC Ogilvie and M Cerman (eds) European Proto-Industrialization (Cambridge: Cambridge University Press, 2nd edn, 1996) pp 118-136.

14. Blackbourn, above n 11, pp 31-34. 
Codification was one possible response to these pressures. The application of a uniform code of laws throughout a state allows a sovereign to consolidate his powers, while also giving him the scope to reform the law and legal institutions to the extent necessary. It also fits with Enlightenment ideals, such as the notion of the 'Law of Reason' or 'Natural Law' ${ }^{15}$ Codification did not, however, necessarily mean adoption of the Code Napoleon. Other, competing, codes also existed at the time which could in theory have formed the basis for codification in the German States. The grand Prussian project to create a uniform code - the Allgemeines Landrecht (ALR) - had only recently been completed and was greatly influenced by many ideas of the Enlightenment. The Prussians had also intended it to be universal in its basis - the draft was circulated throughout Europe and comments were invited from jurists outside Prussia. ${ }^{16}$ The Austrian Allgemeines bürgerliches Gesetzbuch (ABGB), nearly four decades in the making, was also under preparation, and came into effect in 1811. ${ }^{17}$ There was also the option of adopting partial, reforming codes as Bavaria had done in the mid-eighteenth century.

Napoleon tried to push for the adoption of the Code Napoleon throughout Germany, forcing it upon the states he had annexed (the Rhine departments and the Hanseatic cities), and advocating its adoption in the others. ${ }^{18}$ Westphalia, Berg, Frankfurt, Ahremberg and Anhalt-Köthen adopted the Code more or less as it was, Baden did so with significant changes. Nassau and Würzburg adopted the Code but did not bring it into effect. Hesse-Darmstadt and Bavaria began work for its adoption but abandoned or shelved their projects. Other states made no move towards adopting it, in no small part because it eventually became evident that Napoleon was not going to press for its adoption beyond a point. ${ }^{19}$

Adoption was not the end of the story, however. The degree of implementation also varied significantly. Frankfurt, for example, in its decree bringing the Code into force added a provision to the effect that the Code would be supplemented by local custom and civil precedent where the Code itself was silent. Courts and officials in the countryside were so creative in their use of this provision that the Code was, in effect, only followed in the cities. ${ }^{20}$ Anhalt-Köthen presents a similarly interesting case, in that it adopted the code with apparent enthusiasm, but only retained it for a prief period of time before abandoning it in 1812, even before the fall of Napoleon. ${ }^{21}$

There were also differences among states that did not adopt the Code. Some, such as Prussia and Bavaria, implemented sui generis reforms which were at least partially liberalising in social and economic terms. ${ }^{22}$ Others, such as Saxony, did almost

15. F Wieacker A History of Private Law in Europe [Tony Weir (transl)] (Oxford: Clarendon Press, 1995) pp 257-260.

16. Ibid, p 264.

17. Ibid, pp 267-269.

18. Weinacht, above $\mathrm{n} 7$, at 207-208.

19. Fehrenbach, above $\mathrm{n} 8, \mathrm{p} 45$.

20. Ibid, pp 43-44.

21. W Schubert Franzsisches Recht in Deutschland zu Beginn des 19. Jahrhunderts: Zivilrecht, Gerichtsverfassungsrecht und Zivilprozessrecht Forschungen zur neueren Privatrechtsgeschichte, bd. 24 (Kln: Bhlau, 1977) pp 128-131.

22. P Nolte Staatsbildung als Gesellschaftsreform: politische Reformen in Preussen und den süddeutschen Staaten, 1800-1820 Historische Studien Bd 2 (Frankfurt: Campus, 1990). 
nothing, ${ }^{23}$ and some, such as Württemberg, actually became more autocratic, suppressing many of the freedoms that had hitherto existed. ${ }^{24}$ The ALR was discussed in several states as was the (then incomplete) ABGB, but no state seriously moved towards adopting a code modelled on them or drafted along their lines.

On Napoleon's downfall most of the states that had adopted the Code abandoned it either voluntarily (as in the case of Anhalt-Köthen and the Hanseatic departments), or were forced to abandon it as a result of annexation (as in Westphalia, Ahremberg and Frankfurt). There were three exceptions. Baden, which had voluntarily adopted a modified version of the Code, chose to retain it. The Rhineland and the heartland of the Grand Duchy of Berg, which were annexed by Prussia on the fall of Napoleon, also chose to retain it and - particularly in the case of the Rhineland - fought a long battle to retain it against the Prussian plan to extend the ALR to its new territories. ${ }^{25}$ In all three cases, the Code Civil remained on their statute books until the BGB came into force. ${ }^{26}$

\section{THE METHOD: FUZZY-SET QUALITATIVE COMPARATIVE ANALYSIS}

\section{(a) An overview of fuzzy-set QCA}

To a large extent, the difficulties faced by researchers analysing the reception of the Code Napoleon in Germany reflects a basic problem intrinsic to comparative analysis. Because of the difficulties in making in-depth, meaningful comparison across a large number of cases, researchers are typically forced down one of two paths: in-depth analysis of a small number of cases or an analysis which explores a large number of cases but necessarily more superficially, and at risk of losing the in-depth insight into the complexity of individual cases. The former approach is the usual approach adopted in comparative law, and was taken in most of the prior work about the Code Napoleon, but the latter is also present in comparative law.

Qualitative comparative analysis steers a middle ground between these two extremes, allowing researchers to extend the number of meaningful comparisons without losing the in-depth understanding provided by the best case-study analyses. ${ }^{27}$ Central to QCA is the use of set-theory and Boolean logic to analyse combinations of causal conditions associated with an outcome of interest. A researcher starts by identifying the outcome in which he is interested (in our case, adoption of the Code Napoleon), and the conditions which could potentially cause that outcome (for example, having been annexed by Napoleon). The researcher then assesses the presence or absence of these conditions in each of the cases in the analysis. The goal is to identify what combinations of factors have occurred, which of these have produced the outcome in which he is interested and which have not produced that outcome. The researcher then uses Boolean logic to identify necessary and sufficient conditions

23. JJ Sheehan German History, 1770-1866 The Oxford History of Modern Europe (Oxford: Clarendon Press, 1993) p 274.

24. G Lefebvre Napoleon vol 1 [HF Stockhold (transl)] (London: Routledge, 1969) p 239.

25. W Wagner 'Geltungsbereiche ausländischer Kodificationen im Deutschen Reich vor Inkrafttreten des BGB' (1987) 14 Ius Commune 203 at 211-216.

26. Wieacker, above n 15, p 274.

27. B Rihoux 'Qualitative comparative analysis (QCA) and related systematic comparative methods: recent advances and remaining challenges for social science research' (2006) 21 International Sociology 679 at 680. 
which produce the outcome of interest. The researcher takes this result and attempts to interpret what it means - in causal terms or otherwise - by going back to the cases and relating the outcome to the actual circumstances seen in the cases. ${ }^{28}$ Ragin describes this back-and-forth process a 'dialogue between theory and evidence'. ${ }^{29}$

Standard ('crisp-set') QCA relies on the use of dichotomous variables: this approach would have required us to make an assessment of whether a particular state adopted or did not adopt the Code Napoleon. However, it is artificial and quite limiting to divide our cases into states which adopted the Code Napoleon and those which did not, since some states may have adopted the Code with minor or less minor amendments, while others may have drawn more or less heavily from the Code in pursuing their own codification projects. Fuzzy-set QCA allows for more variegated measures by introducing the idea of degrees of membership of a given set, with each condition in each case assigned a fuzzy score between 1.0 (for 'full membership') of a set and 0 for ('full non-membership'). Intermediate values are 'calibrated' in accordance with defined criteria. Full details of the coding and the criteria used for all the conditions in our analysis are given in the Appendix; see especially Table 1. As this example illustrates, fsQCA is particularly suited to the question we ask, allowing different cases to be classified as having different degrees of membership of the set of 'adopters of the Code Napoleon' and of the sets of causal conditions in the analysis.

There are a number of attractive features of such an approach to analysis. First, as Ragin points out and as we discuss further in the next section, QCA formalises what many comparatively oriented social scientists, including comparative lawyers, already do implicitly. Moreover, by formalising the process, QCA requires us to identify systematically every factor we take into account in our analysis and consistently to use the same expressly stated criteria in assessing the strength of the factors in every country that forms a part of our study. The formalism and systematic attention to method enhances the integrity of the analysis. Cumulatively, they reduce the danger that a comparative study becomes impressionistic, or merely provides post-hoc rationalisation of the researcher's prior beliefs which remain unchanged (and unchallenged) by confrontation with the data. Moreover, fsQCA encourages (and facilitates) a more systematic and considered selection of cases for comparison and thereby helps in addressing the issue of selection bias which plagues many comparative studies in law and more generally.

In terms of limitations, it is important to recognise that QCA (and its extensions) do not provide a substitute for the careful judgement and analysis exemplified in the best case-study analyses; nor are they intended to offer an alternative to the techniques of 'numerical comparative law'. ${ }^{30}$ But, as we hope the following sections will demonstrate, the techniques described here do offer a compelling alternative to both these approaches under a number of constraints: where the number of cases are too few to approach through statistical analysis, yet numerous enough to make comparison cumbersome. QCA has an important part to play in extending the reach and power of comparative legal analysis. Accordingly, it deserves a prominent place in every comparative lawyer's repertoire of analytical techniques.

28. AM Herrmann and L Cronqvist 'When dichotomisation becomes a problem for the analysis of middle-sized datasets' (2009) 12 International Journal of Social Research Methodology 33.

29. CC Ragin Fuzzy Set Social Science (Chicago: University of Chicago Press, 2000) ch 11. 30. MM Siems 'Numerical comparative law - do we need statistical evidence in law in order to reduce complexity?' (2005) 13 Cardozo Journal of International and Comparative Law 521. 


\section{(b) Applying QCA to the problem}

The technical details of the process of using fsQCA to analyse the factors behind the adoption and retention of the Code Napoleon are set out in an Appendix. This subsection provides a broad overview of the process.

There were a total of 39 states in the Confederation of the Rhine. Adding the Rhine and Hanseatic departments annexed by Napoleon (as one unit each), we arrive at a total of 41 . Of these, we selected and analysed 14 states, constituting about a third of the possible cases. In choosing the cases for analysis, we included all cases where the Code was adopted and were careful to ensure that the remaining cases represented the entire range of outcomes from outright rejection to partial adoption. Our case selection also ensured that a diverse range of states were included in terms of geographical location, economy and size, while still keeping the study manageable. It is worth noting that while we restricted the study to 14 cases, the method used could have easily been scaled up to study all 41 possible cases.

We began by identifying the outcomes in which we were interested (ie adoption or non-adoption of the Code during the Napoleonic period, and its retention or rejection after Napoleon's defeat). The next step was to identify factors that might have influenced the decision to receive or not receive the Code Napoleon. In QCA, the identification of potential causal conditions is based on the researcher's substantive knowledge of the area under investigation - researchers select variables they think are likely to have influenced the outcome under consideration, based on their expertise in the area. Thus, for example, there is a clear connection between the geographical location of a state and the likelihood of its adoption of the Code Napoleon - no state further east than Anhalt-Köthen came anywhere near adopting the Code, and Anhalt itself only kept the Code for a very short time. ${ }^{31}$ Yet in the context of nineteenth century Germany, geographical location is unlikely to be a causative factor; rather, it is likely to reflect underlying cultural, social, economic, political or other conditions that were causative, and the aim of this stage should be to identify those factors. Similarly, the key issues on which debates about the adoption of the Code Napoleon focused were feudal property relations and familial relations, particularly marriage and the relationship between husband and wife. ${ }^{32}$ Despite the fact that all three issues were important in the rhetoric surrounding the debate, our research suggested that there did not appear to have been a significant degree of variation in attitudes to women or the family across Germany in that period. This particular factor is therefore unlikely to explain the differences in states' responses to the Code Napoleon.

Our selection of potential causal conditions therefore springs from our understanding of the social, economic, political and legal history of Germany and of the individual German states in the eighteenth and nineteenth centuries, and is obviously also informed by the specific arguments and rhetoric that were used at the time in debates and discussions on the question of whether or not to adopt the Code. The factors we used as the basis of our analysis were the extent of territorial diversity created in the Napoleonic period, the degree of control or influence by Napoleon, the degree to which the economy and polity was feudal, the strength of central state institutions, the degree to which liberal ideas (in the eighteenth century German context) influenced the state's policies, the extent to which the state's government displayed nativist tendencies, and the extent to which anti-French sentiment prevailed. The narrative in

31. Wagner, above $\mathrm{n} 25$, at 206.

32. Hull, above n 5, p 373. 


\section{Legal Studies, Vol. 30 No. 1}

section 3 should give a better sense of what these factors mean and why we selected them.

The next step was to assess the strength of the seven factors and two outcomes for each of the 14 cases we studied, and assign them values on a scale of 0 to 1 calibrated according to benchmarks we identified. Having done this, we were in a position to use the logical techniques of fsQCA to identify which of the potential causal conditions actually contributed to the outcomes, and in what combination. Both these steps are fairly technical and are described in the Appendix. In the next section, we present our results and interpret what they mean by looking at them in relation to the cases and factors we used as the basis of our analysis.

\section{FACTORS AND FINDINGS}

In relation to the adoption of the Code Napoleon, a key factor that emerged from our analysis was liberalism - as our findings showed, if a single factor had to be chosen, it would be liberalism. No state with a conservative ruler adopted the Code - a reluctance which, according to our analysis, was heightened by the presence of anti-French sentiment in the general populace, relative independence from Napoleonic interference, influential feudal classes, strong central administrative institutions and a high degree of nativism or local patriotism amongst the ruling classes.

Liberalism by itself was not, however, sufficient to produce a decision to adopt the Code - some liberal states, such as Bavaria, did not adopt the Code. Almost all states which adopted the Code not only had liberal rulers, but had also added to their territory during the Napoleonic period, and consequently now ruled areas which were different either in social terms, or which were governed by a different set of laws or had different administrative arrangements. In addition, they also fell into one of two classes. The first were states which were subject to a high degree of control by Napoleon, which adopted the Code if nativism - or local patriotism was not a strong factor amongst the ruling classes, and if their central institutions were weak. The second were states where feudal influences existed - that is, where the economy was largely feudal and where the feudal classes were politically influential - and where the population was not strongly anti-French. In contrast, states where strong feudal influences were combined with a relatively low degree of direct or indirect control or influence by Napoleonic France, a high degree of local patriotism amongst the ruling classes and strong central institutions tended not to adopt the Code even if their rulers were liberal and they had a high degree of territorial diversity.

In the remainder of this section, we explore what these findings mean by looking in turn at each of the factors we studied and examining why they had the impact they did.

\section{(a) Territory, diversity and legitimacy}

The territory of Germany was radically transformed in the Napoleonic period. The number of states was brought down from over 300 (or nearly 2500, if the holdings of imperial knights are counted) to 39. At the peak of the Napoleonic Empire, historical Germany consisted of four entities: the provinces annexed by France, the 
Confederation of the Rhine, Prussia and Austria. ${ }^{33}$ The mediatisation of the small states diminished the power of many of the traditional German elites, such as imperial knights and (in some but not all areas) the locally dominant church, and changes in territorial control disrupted existing relations between classes of society and the state. Yet, more problematically for states, they created problems of territorial diversity.

Diversity occurred at several levels. Enlarged states faced a diversity of legal systems, institutions and customs within their territory. In Baden - which had increased fourfold in size and sixfold in population - no less than eight different legal systems were in effect: those of Baden-Durlach, Baden-Baden, Speier, Mainz, the Palatinate, Würzburg, Württemberg and the incomplete ABGB. ${ }^{34}$ The situation in other states was even worse - Berg's territory had been cobbled together from the lands of 15 different sovereigns, each with its own laws, codes and customs..$^{35}$ Legal diversity at this level created obvious problems of administration, to which a common code was an obvious answer, and the issue of the need to address legal diversity was expressly raised as part of the discussions surrounding the question of whether to adopt the Code in German states with significant levels of territorial diversity, such as Baden. ${ }^{36}$ It also had precedent: previous codifications - such as the Prussian ALR and the Austrian ABGB - were driven at least in part by a desire to unify the law in a newly expanded state ${ }^{37}$. The Code Napoleon itself had been in no small part motivated by the desire to create a unified code of laws for all of France. ${ }^{38}$

More importantly, however, enlargement created issues of legitimacy and sovereignty for the newly enlarged states. The German states in the immediate preNapoleon period were, for the most part, still pre-modern territorial states, which were principally defined by the fact that they were subject to the jurisdiction of their ruler. ${ }^{39}$ From an institutional point of view, therefore, the territorial changes during the Napoleonic period - and the fact that the annexed territories were governed by laws and administred through structures that reflected a different ruler's jurisdiction created a serious question of legitimacy for the states that acquired new territories. ${ }^{40}$

Legal and administrative reforms were one way of attempting to affirm a state's sovereignty in areas that it had recently acquired by transferring jurisdiction - and hence the perception of sovereignty - from the local to the centre. ${ }^{41}$ The bureaucratic state had begun to occupy a central place in German affairs by the the second half of the eighteenth century ${ }^{42}$ and, as a result centralisation, usually took the form of an expansion of the bureaucracy - both in terms of numbers and in terms of the areas of life it regulated - usually at the expense of traditional local privileges and autonomy. ${ }^{43}$ The aim behind these moves was principally to strengthen the position of the central

33. Grab, above $\mathrm{n} 10, \mathrm{p} 90$.

34. Blackenburg, above $\mathrm{n} 4, \mathrm{p} 213$.

35. Grab, above n 10, p 97.

36. Weinacht, above $\mathrm{n} 7$, at 213 .

37. Wieacker, above $\mathrm{n} 15$, pp 261 and 266.

38. R Cassin 'Codification and national unity' in B Schwartz (ed) The Code Napoleon and the Common Law World (New York: New York University Press, 1956) pp 46-54 at pp 46-49.

39. Blackbourn, above n 11, p 14.

40. ED Brose German History, 1789-1871: From the Holy Roman Empire to the Bismarckian Reich (Oxford: Berghahn Books, 1997) p 53.

41. M Walker German Home Towns: Community, State, and General Estate, 1648-1871 (Ithaca: Cornell University Press, 1998) p 197.

42. J Sheehan German Liberalism in the Nineteenth Century (London: Methuen, 1982) p 35.

43. Walker, above n 41, pp 198-210. 
state as the guardian of the intersts of society ${ }^{44}$ and, if possible, to win popularity by empowering rising elites who chafed under the old order. ${ }^{45}$ As a result, the issues of constitutionalism and the reception of French administrative institutions and structures played a significant part in debate on the question of the adoption of the Code, ${ }^{46}$ whose adoption was seen as being key to receiving French administrative institutions. This provides some context to our results, which suggest that territorial diversity and weak institutions were jointly responsible for adoption in a number of states, and that the presence of strong institutions contributes to the rejection of the Code.

We therefore see that virtually no state in which territorial diversity was altogether absent adopted the Code - the one exception was Anhalt-Köthen, to which we will return in section 3(d). Yet states with relatively strong central institutions - such as Bavaria and Württemberg - did not adopt the Code, even though they had high levels of legal and social diversity. Logically, states with strong central administrative institutions in their core territories would have had relatively little difficulty in extending these institutions to their newly acquired territories, and would have been correspondingly less likely to need to transplant French institutions wholesale. States with weak administrative institutions, and even more so newly created states which had no central institutions at all, on the other hand, would have had more to gain from transplanted French administrative institutions and hence would have been more likely to consider the adoption of the Code Napoleon. We therefore see that Bavaria chose to enact sui generis reforms, while the ruler of Württemberg resolved the problem by becoming an absolute autocrat and abolishing all traditional privileges. States with relatively strong institutions which did adopt the Code - such as Baden tended to do so with major modifications. The most faithful adoptions of the Code occured in Westphalia, Ahremberg, Berg and Frankfurt, where no central institutions to speak of existed.

\section{(b) Liberalism, feudalism and reform}

The eighteenth century had seen a rise in liberal ideas in Germany, as elsewhere in Europe, and the early idealistic period of the French Revolution had a particularly strong impact in many parts of Germany, the result of which was a rising liberal sentiment. Liberalism affected the ruling classes as well, though to varying degrees, and sometimes only to turn them against the idea. At one extreme were states such as Bavaria, one of whose chief counsellors was so liberal that he was suspected of secretly being a member of the Illuminati ${ }^{47}$ and Hesse-Darmstadt, whose Grand Duke was himself suspected to be an Illuminatus. ${ }^{48}$ At the other extreme were states like Württemberg, which under Frederick II instituted censorship, prohibited public meetings and ended the independence of universities, despite - or possibly because of - the state being home to a large number of prominent liberals. ${ }^{49}$

44. Blackbourn, above $\mathrm{n} 11, \mathrm{p} 77$.

45. Brose, above n 40, p 53.

46. Fehrenbach, above n 8, pp 7-39.

47. GP Gooch Germany and the French Revolution New impression edition (London: Frank Cass \& Co, 1965) pp 494-496.

48. Ibid, pp 456-457.

49. Lefebvre, above n 24, p 244. 
The Napoleonic codes were grounded in liberal ideals, particularly the ideas of freedom of the individual and equality before the law. ${ }^{50}$ The liberal, progressive base of the Code Civil, in particular, was frequently stressed in the rhetoric of its proponents. For example, Feuerbach in Bavaria expressly drew a contrast between the old ideas of the prevailing order and the new, humanistic ideas of the Code. ${ }^{51}$ Years later, the German revolutionaries of 1848 still held the Code up as the most perfect of all legal codes. ${ }^{52}$ On the face of it, therefore, one would expect states where liberal ideas were strong and had influence on policy making to move towards adopting the Code Napoleon. ${ }^{53}$ Our results bear this out. As discussed above, our results show that liberalism was a strong necessary condition for the adoption of the Code - no conservative state adopted the Code, and if one single factor had to be singled out as an explanation, it would be liberalism.

Liberalism as a factor did not, however, occur in isolation. The territorial changes brought about by the Napoleonic period gave added importance to liberal policies and their link to the Code. The numerous boundary changes of the Napoleonic period created an unprecedented amount of social diversity within states. The core of the enlarged Grand Duchy of Baden, for example, was the old state of Baden Durlach. This state had historically been Protestant, but, after enlargement, the new Grand Duchy had a significant Catholic majority. ${ }^{54}$ Württemberg, another historically Protestant state, acquired a large Catholic minority and a significant Jewish population. ${ }^{55}$ Bavaria, a Catholic state, acquired a large Protestant minority. Not all minorities were pleased with their assimilation into a state with a different religious background - in the worst cases, it led to actual rebellion. ${ }^{56}$ Against this backdrop, the key liberal principles of religious liberty and civil equality to all religions championed by Napoleon had obvious attactions, and were an obvious way for a sovereign to establish himself amongst his new subjects. ${ }^{57}$ Thus, our findings demonstrate a strong link between the combination of liberalism and territorial diversity, and the adoption of the Code.

Yet the link between liberalism and territorial diversity also contains a paradox. Our findings show that some states where liberalism was strong and whose territory and societies had become increasingly diverse as a result of their enlargement did not adopt the Code. A closer examination of the cases shows that, somewhat counterintuitively, the most liberal states were less likely to adopt the Code unaltered, once other circumstances such as control are taken into account. The states which adopted the Code most faithfully tended to be clustered around the middle on a spectrum of liberalism. In the most liberal states, the Code was either adopted with a number of exceptions, or not adopted at all. In Frankfurt, ruled by the liberal Prince-Primate Dalberg, the Code was adopted with so many exceptions that the countryside continued to conduct its affairs almost as if it had not been adopted. ${ }^{58}$ Baden's government under Karl Friedrich, whose advisors included von Schlosser and Brauer, has

50. Wieacker, above n 15, pp 273-274.

51. Fehrenbach, above n 8, pp 49-50.

52. Weinacht, above $\mathrm{n} 7, \mathrm{p} 208$.

53. van Caenegem, above $\mathrm{n} 1, \mathrm{pp}$ 48-50.

54. N Hope German and Scandinavian Protestantism: 1700-1918 (Oxford: Clarendon Press, 1995) p 328.

55. EC Rose Portraits of our Past: Jews of the German Countryside (Philadelphia: Jewish Publication Society, 2001) pp 45-46.

56. Blackbourn, above n 11, pp 77-78.

57. Hope, above n 54, pp 327-329.

58. Fehrenbach, above n 8, pp 43-44. 
been called the best example of enlightened German absolutism, ${ }^{59}$ yet in its implementation, several hundred articles were added to the Code, so that nearly a fifth of the Code was new and many of its original provisions singificantly altered. ${ }^{60}$ Bavaria rejected the Code altogether and Nassau, where Fredrick Augustus' advisors included the likes of Marschall von Biberstein, nominally adopted the Code but never brought it into effect. ${ }^{61}$

A possible explanation for this paradox lies in the legitimacy which a prestigeous transplanted law conveys. ${ }^{62}$ A state whose ruling classes were established liberals would require a lesser degree of legitimisation than a state where liberalism was less strongly established. The former were therefore freer to craft their own compromises, and to strike their own balances between making concessions to established interests - such as feudal or aristocratic interests - and pursuing the modernising reforms they desired to implement, without necessarily being tied to the original form of the Code Napoleon or the particular compromises it struck. We see, therefore, that liberal states which did not adopt the Code did implement independent liberal reforms. Nassau adopted a constitution in 1814, which was drafted, in large part, by Marschall von Biberstein and implemented many liberalising reforms. ${ }^{63}$ Similarly, Bavaria's 1808 constitution, drafted by Montgelas, modernised the administration and was accompanied by a string of other liberalising reforms (such as the removal of all restrictions on Protestants and guaranteeing a free press).$^{64}$

The second factor to which our research shows liberalism as being linked was the nature of the economy and, in particular, the strength of the feudal classes. The radical changes which the Code made to the system of land rights and land tenure would have hit feudal aristocrats hard, although with differing results in the Grundherrschaft system of southern Germany, where the aristocracy lived off rents rather than farming the land themselves, as many of their northern counterparts did in states following the Gutsherrschaft system. ${ }^{65}$ Across Germany, these provisions were amongst the most hotly debated in the course of the discussions surrounding the reception of the Code, and frequently led to head-on clashes between liberals who favoured the adoption of the Code, and feudal interests who opposed it. ${ }^{66}$ Feuerbach's attempts to prepare a Code for Bavaria based on the Code Napoleon, for example, led to a bitter protracted battle with the Bavarian aristocracy, whose determined opposition ultimately led to the abandonment of the project to introduce the Code into Bavaria. ${ }^{67}$ Saxony and Württemberg, which were both feudal and conservative, did not even seriously consider receiving the Code Napoleon. Even a state like Westphalia, where feudal classes had very little practical power because the state had been created ex nihilo, boasted of

59. G Schachter and S Engelbourg Cultural Continuity in Advanced Economies: Britain and the US versus Continental Europe (Aldershot: Ashgate, 2005) p 65.

60. Fehrenbach, above n 8, p 41.

61. Blackenburg, above $\mathrm{n} 4$, pp 267-269.

62. JM Miller 'A typology of legal transplants: using sociology, legal history and Argentine examples to explain the transplant process' (2003) 51 American Journal of Comparative Law 839 at $845-858$.

63. H-W Hahn Wirtschaftliche Integration im 19. Jahrhundert: die hessischen Staaten und der Deutsche Zollverein Kritische Studien zur Geschichtswissenschaft, bd. 52 (Göttingen: Vandenhoeck \& Ruprecht, 1982) pp 30-32.

64. A Ramm Germany 1789-1919: A Political History (London: Methuen, 1967) pp 76-79.

65. E Sagarra A Social History of Germany, 1648-1914 (London: Metheun, 1977) p 188.

66. Fehrenbach, above n 8, pp 18-26.

67. Ibid, 46-51. 
how it had applied the anti-serfage and feudal principles of the Code in a manner which demonstrated an 'equitable temperament', in contrast with Genoa where they were enforced more rigidly. ${ }^{68}$ The most feudal state which adopted the Code was Baden - whose peasants were counted amongst the freest in Europe, ${ }^{69}$ and where liberal sentiments were exceptionally strong. Even so, Baden saw the most drastic revisions to the Code. The portion of the Code dealing with property was completely overhauled, guaranteeing the survival of large estates and perpetuating many obligations of the peasantry. ${ }^{70}$

In comparison, the rules in the Code seem to have been much more attractive to the business community. With the exception of a few isolated provisions - such as its rules on mortgages and some others - the Code was perceived as being friendly to commerce. This perception sprung from the Code's affirmation of every individual's freedom of economic and contractual activity, which contrasted sharply with the privileges of guilds and other bodies under the old system in Germany. Napoleon, too, went to some lengths to woo the bourgeoise, even those who may have been expected to be inclined against him. This was particularly true of the territories he annexed earlier. In the Rhineland, for example, this was accomplished through allowing all those who possessed wealth and talent, including radicals, to obtain jobs in the Napoleonic bureaucracy. ${ }^{71}$ The forced alienation of Church land (and emigré property) worked to the advantage of the dominant bourgeoise, who enlarged their holdings. Manufacturing industry, too, grew rapidly as British competition was kept away. ${ }^{72}$ As a result, the Rhenish business community was at the forefront of the - ultimately successful - campaign to retain the Code Napoleon as 'Rhenish law' after the territories' absorption by Prussia. ${ }^{73}$ Similarly, of the three 'model' states created by Napoleon, the most faithful implementation of the Code occurred in Berg, which had a strong proto-industrial heartland and where feudalism was particularly weak. Like the Rhineland, the industrial heartland of Berg (which roughly corresponded to the territory of the historical Duchy of Berg) campaigned hard - and successfully against its new Prussian masters to be allowed to retain the Code. ${ }^{74}$ This stood in sharp contrast to the less industrial and more agrarian regions of the Napoleonic Grand Duchy of Berg, such as Cleves and the County of the Mark, which were content to see the Code Napoleon, many of whose provisions they disliked, swept away and replaced by the Prussian ALR. ${ }^{75}$

\section{(c) Localism, loyalty and anti-French sentiment}

Our findings also show that liberalism, territorial diversity, weaker feudal classes and the other factors discussed above only operated in the absence of nativism or anti-

68. HAL Fisher Studies in Napoleonic Statesmanship: Germany (Oxford: Clarendon Press, 1903) p 257.

69. Sheehan, above $\mathrm{n} 23, \mathrm{p} 272$.

70. W Andreas 'Die Einführung des Code Napoleon in Baden' (1910) 31 Zeitschrift der Savigny-Stiftung für Rechtsgeschichte: Germanistische Abteilung 182 at 218-227.

71. M Rowe 'Between empire and home town: Napoleonic rule on the Rhine' (1999) 42 Historical Journal 643 at 648-649.

72. Grab, above n 10, p 94.

73. JM Diefendorf Businessmen and Politics in the Rhineland, 1789-1834 (Princeton, NJ: Princeton University Press, 1980) pp 255-259 and 283-284.

74. C Schmidt Le Grand-Duché de Berg (1806-1813) (Paris: Ancienne Librairie Germer Bailliere, 1905) p 225.

75. Ibid, pp 220-5. 
French sentiment. Eighteenth century German liberalism was a lot more complex than was the liberalism that develped in England and Scotland during the Enlightenment. ${ }^{76}$ Nineteenth century German liberals believed in the idea of a Rechtsstaat - a state ruled by law - and in the guarantee of certain basic substantive and procedural rights including an end to arbitrariness. ${ }^{77}$ But liberals did not necessarily believe in free trade, nor were they necessarily republicans, and most liberals of this period were not democrats. Their liberalism was, instead, drawn from the Aufklärung idea of enlightened monarchic rule and, as a result, was peculiarly susceptible to nativism, local patriotism or loyalty to the local ruler. The result was that, in some regions, liberal and even pro-revolutionary sentiment was accompanied by lukewarm sentiment towards French institutions, including the Code. In the Rhineland, for example, many liberals were content with the mild reforms instituted by their rulers in the late eighteenth century and the overall social and economic progress their territories had made. ${ }^{78}$ In Württemberg, there was talk amongst radical liberals of an Allemannic Republic but little desire to transplant French institutions or theories. ${ }^{79}$ While more radical, universalist liberals, such as the German Jacobins, existed in many parts of Germany, ${ }^{80}$ they were always a small minority and their overall influence on policy and public opinion was negligible. ${ }^{81}$ The general revulsion engendered in German intellectual and policymaking circles by the Reign of Terror in France, and the excesses of the French occupation of the Left Bank in the pre-Napoleonic period, reduced what influence they had even further as they came to be tainted by their association with the French occupation. $^{82}$

Localist or nativist sentiments had a particularly strong resonance in early nineteenth century Germany, whose political landscape was still dominated by territorial states. 'Sovereignty' in such states was closely linked to jurisdiction, and forcible imposition of a foreign code would therefore have been viewed as an act of usurpation, particularly where it was accompanied by the destruction of traditional local institutions (as happened in, for example, Hamburg and the other Hanseatic cities) ${ }^{83}$ This was accentuated by a thread within the Protestant Enlightenment in Germany, represented by the thought of people such as Herder, which highlighted and glorified the importance of the local and national, as opposed to the classicised ideal of the universal that was central to the French Enlightenment. ${ }^{84}$

76. J Schmidt 'Liberalism and enlightenment in eighteenth-century Germany' (1999) 13 Critical Review 31.

77. Blackbourn, above n 11, pp 130-131.

78. TCW Blanning The French Revolution in Germany: Occupation and Resistance in the Rhineland, 1792-1802 (Oxford: Oxford University Press, 1983) p 57.

79. Gooch, above n 47, p 507.

80. W Grab Norddeutsche Jakobiner: Demokratische Bestrebungen zur Zeit der Französischen Revolution Hamburger Studien zur neueren Geschichte, band 8 (Frankfurt: Europäische Verlagsanstalt, 1967).

81. TCW Blanning, 'Review: German Jacobins and the French Revolution' (1980) 23 The Historical Journal 985 at $991-996$.

82. M Rowe From Reich to State: Tthe Rhineland in the Revolutionary Age (Cambridge: Cambridge University Press, 2003) pp 81-82.

83. Crosby, above n 6, pp 68-71.

84. BW Redekop Enlightenment and Community: Lessing, Abbt, Herder and the Quest for a German Public (Montreal: McGill-Queen's University Press, 2000) pp 198-202. 
Accordingly, many regions, such as Bavaria, Baden and Württemberg, displayed a palpable mood of local patriotism, ${ }^{85}$ which makes frequent appearances in the discussions around the adoption of the Code Civil. In Baden, for example, Brauer strongly opposed the Giessen Conference's project of preparing a uniform German version of the Code Civil, arguing that this was incompatible with Baden's independence ${ }^{86}$ In Bavaria, the idea that there was a unique Bavarian character which the law should reflect was used to oppose the adoption of the Code Civil. ${ }^{87}$ This sentiment, coupled with the reforms which some states had carried out, meant that many who supported the ideals of the French Revolution and the Code Civil saw no reason for its introduction in their own, more enlightened states. ${ }^{88}$

A phenomenon closely related to liberalism was the anti-French sentiment, which manifested itself strongly in many areas of Germany. In some places, such as Berg, Hamburg and Saxony, it manifested itself in rebellion against the French. ${ }^{89}$ Elsewhere, it manifested itself in more subtle forms, such as through deliberate participation in smuggling or transmitting contraband goods, or other forms of indirect passive resistence. ${ }^{90}$ The role of national sentiment in creating and consolidating opposition to the Code Napoleon in the Netherlands is fairly well known. ${ }^{91}$ Similar arguments were also marshalled in Germany, where the existence in force of a foreign code in Germany was portrayed as being against German national pride. Rehberg's anti-Code polemic, written towards the close of the Napoleonic period, for example, emphasises the French, foreign nature of the Code, and its usurpation of the place that should rightfully be occupied by the native, German legal thought and principles that Germans held dear. ${ }^{92}$

The link between anti-French sentiment and the decision to reject the Code, which our findings highlight, is striking. Anti-French sentiment was strongest in northern and eastern Germany, possibly because the hardships caused by French rule and military occupation made the urban artisan and middle classes particularly receptive to antiFrench propaganda and significantly weaker in southern Germany. ${ }^{93}$ No northern or eastern state adopted the Code, and the farthest east it travelled was Anhalt-Köthen, ${ }^{94}$ which, as will be discussed in section $3(\mathrm{~d})$, is a special case.

The combination of nativism and anti-French sentiment also affected the business community and other intermediate elites, whose 'buying in' into the Napoleonic system was not universal. Unlike the rest of the Rhineland, Cleves willingly abandoned the Code Napoleon at the end of the Napoleonic period..$^{95}$ Its Prussianised elites

85. PW Schroeder The Transformation of European Politics: 1763-1848, The Oxford History of Modern Europe (Oxford: Oxford University Press, 1996) p 378.

86. Blackenburg, above n 4, pp 220-221.

87. Ibid, p 287.

88. Blanning, above $\mathrm{n} 81$, at 993 .

89. Grab, above n 10, p 109.

90. PG Dwyer Napoléon and Europe (Harlow: Longman, 2001) pp 109-110.

91. G Meijer and SYTh Meijer 'Influence of the Code Civil in the Netherlands' (2002) 14 European Journal of Law and Economics 227.

92. AW Rehberg Ueber den Code Napoleon und dessen Einführung in Deutschland (Hannover: Hahn, 1814) pp 6-8 and 11-15.

93. K Hagemann 'Francophobia and patriotism: anti-French images and sentiments in Prussia and northern Germany during the anti-Napoleonic wars' (2004) 18 French History 404 at 406 and 423-424.

94. Wagner, above $\mathrm{n} 25$, at 206.

95. Schmidt, above n 74, p 225. 
had made a point of rejecting Napoleon - at the time of its original annexation, they chose to withdraw to unannexed Prussian territories, despite having earlier supported Franco-Austrian forces in the Second Year War. ${ }^{96}$ This reflected the broader rejection by the Prussian elites, including the commercial classes, of Napoleonic ideas as 'anti-German' following his invasion of Prussian territory, despite having earlier welcomed those very ideas. ${ }^{97}$ Similarly, the Hanseatic ports, which were commercial centres, forcefully resisted the implementation of the Code and willingly abandoned it when they could. Unlike the Rhineland, the Napoleonic period had seen the ruin of their economies, which depended strongly on trade with England and were therefore ravaged by military occupation and the continental blockade. ${ }^{98}$

Yet, contrary to what writers such as Crosby suggest, nativism or anti-French sentiment did not in and of themselves determine whether the Code Napoleon was adopted or retained. Our findings show that nativism was not an absolute or dispositive factor - it could be, and was, countered by other factors. Despite the strong nativism of the Rhineland, the long period for which it was under Napoleonic control meant that the Code became the law there. And for all Baden's strong nativism, the combined effect of a strong strain of liberalism, diversity and the relatively weaker power of the feudal classes meant that nativism only resulted in the Code being 'localised', not rejected altogether. Similarly, lawyers and judges were not uniformly opposed to the Code Napoleon across Germany. Some, such as the Romanist jurists of Frankfurt, did indeed lead opposition to the Code, but others, such as the Rhenish jurists, campaigned for the Code to be retained after the fall of Napoleon - in their case, the Code's connection with liberalism, the ending of the diversity of laws that applied across the Rhineland and the interests of the commercial sector overrode any opposition that nativism might have been expected to engender.

More strikingly, it was the most strongly nativist and anti-French places that eventually retained the Code Napoleon after Napoleon's defeat. The states of the left bank of the Rhineland saw the growth of a strong nativist and anti-French sentiment in the years of French military occupation, ${ }^{99}$ but the Rhineland nonetheless ended up being an enthusiastic supporter of the Code. The industrial heartland of Berg, roughly corresponding to the area that had been part of the seventeenth century Duchy of Berg, was in 1813 the site of a bitter anti-French revolt which had been brought on by Napoleon's commercial policies. ${ }^{100}$ It nonetheless fought hard - and successfully - to be allowed to retain the Code Napoleon after its absorption into Prussia at the end of the Napoleonic period. Nativist Baden, which did not even want to collaborate with other German states on a uniform version of the Code for fear of undermining its independence, retained its modified Code. Despite occasional muttering about it being a 'foreign law', there was little widespread dissatisfaction. ${ }^{101}$ A particularly stark example of how German notables could support the Code despite nativist sentiments is provided by the case of Christoph Wilhelm Sethe, who, as procurator-general in the court of appeal in Berg, refused to carry out the orders of his French superiors in

96. Rowe, above $\mathrm{n} 71$, at 650 .

97. RM Glassman The Middle Class and Democracy in Socio-Historical Perspective (Leiden: Brill, 1995) p 171.

98. Grab, above n 10, pp 94-95.

99. Blanning, above n 78, pp 207-254.

100. H Kisch From Domestic Manufacture to Industrial Revolution: The Case of the Rhineland Textile Districts (Oxford: Oxford University Press, 1989) pp 206-210.

101. Blackenburg, above n 4, pp 238-241. 
relation to crushing the rebellion against the French. Nonetheless, he argued strongly in favour of retaining the Code Napoleon after Berg's integration into Prussia. ${ }^{102}$

\section{(d) Napoleonic control and influence}

The literature on the adoption of the Code Napoleon in Germany often presents the degree of control exercised by Napoleon over a state as being a factor in the decision to adopt a code, or at least in the degree to which a state adopted or implemented a code. Blackenburg, in his 1931 study of the adoption of the Code Napoleon in Germany, treats this as being the only determinative factor. He says that the efforts and discussions within individual states ultimately played no role in the decision to adopt or not to adopt the Code. This, he argues, was determined solely by the political conditions then prevailing in Europe. States which adopted the Code either had it directly forced upon them through annexation or through imposition by treaty (as in the case of Westphalia), or were indirectly forced to adopt the Code due to their subjugation or subserviency to Napoleon. ${ }^{103}$

Not all modern historians go this far. Brose advances a milder form of this thesis, suggesting that adoption of the Code and other liberalising policies helped rulers preserve their countries' autonomy by reducing the chance that Napoleon would directly intervene. ${ }^{104}$ Napoleon had in fact threatened to intervene and directly assume power when he was frustrated with German princes' lack of response to his demands, particularly in relation to requisitioning of troops and supplies for his army. ${ }^{105}$ Weinacht points out that many of the states which adopted the Code as is were ruled by Napoleon's family, but that it was also adopted by states that were not. ${ }^{106}$ Our analysis goes further, demonstrating how control by Napoleon as a condition operated in combination with other factors. On its own, it was neither a necessary nor a sufficient condition, although states which chose not to adopt the Code to any degree were, invariably, those in which the level of control was limited.

Control is, however, more subtle than direct control or subjugation. An important form of control, keenly felt by small states, was the ever-present threat of mediatisation. A small state believing itself in danger of mediatisation may well have chosen to adopt the Code as a way of attempting to ingratiate itself with Napoleon. This would explain the otherwise anamalous adoption of the Code by Ahremberg (in whose case the fear of mediatisation turned out to be justified, as it was mediatised into Berg in 1810) and Anhalt-Köthen. It would also explain the extremely short existence of the Code in Anhalt-Köthen, which abandoned the Code in less than a year, ${ }^{107}$ by which time it had become clear as a result of Napoleon's correspondence with Almendingen and others at the Giessen conference that the failure to adopt the Code would not be of great consequence. ${ }^{108}$ Similarly, this also explains the adoption of the Code by Ferdinand of Würzburg, who had lost his traditional Tuscan domains to Napoleon but had received Würzburg in compensation, and his failure actually to bring the Code

102. Rowe, above $\mathrm{n} 71$, at 651 .

103. Blackenburg, above n 4, pp 290-291.

104. Brose, above n 40, p 53.

105. Walker, above n 41, p 197.

106. Weinacht, above $\mathrm{n} 7, \mathrm{p} 209$.

107. Schubert, above n 21, pp 128-131.

108. Fehrenbach, above $n 8, \mathrm{p} 45$. 
into effect. Neither Augustus Christian Friedrich nor Ferdinand was a strong liberal, nor had either territory undergone significant expansion.

An even less direct form of influence lay in a state voluntarily choosing to obey what it believed were Napoleon's wishes, in the hope of benefitting from his continued victories - through, for example, acquisition of further territories. Hesse-Darmstadt and Nassau are classic examples - both were, at best, reluctant allies who only sided with Napoleon because it was in their best interests to do so. ${ }^{109}$ Against this backdrop, their adoption of the Code Napoleon without ever bringing it into effect makes more sense.

\section{CONCLUSIONS}

As our analysis shows, no single factor was responsible for the adoption of the Code Napoleon. The factor that comes closest is liberalism, but liberal states, too, were influenced by other factors and, as we have discussed, not all liberal states actually adopted the Code. Similarly, control by Napoleon, while important, was also not determinative - it was, in the ultimate analysis, other surrounding factors which determined the extent to which a state under Napoleonic influence adopted the Code.

On one level, many of the factors discussed by previous scholars were found by us to have played a role in explaining the reception of the Code Napoleon. However, as this article has demonstrated, these factors did not occur or operate in isolation. Our analysis shows how different social and economic factors interacted with each other in determining the course of nineteenth century German legal history. As we have discussed, this interaction produced different combinations of causal factors, each of which contributed to the adoption or non-adoption of the Code. Some of the combinations we have identified initially seem counter-intuitive, but, nonetheless, on analysis can be clearly seen to fit in with what we know of German society and polity in the Napoleonic period. A particularly strong example is provided by our analysis of the complex effect which liberalism could have on the decision to adopt or reject the Code: although liberalism usually favoured the adoption of the Code, a higher degree of liberalism could, combined with a high degree of feudalism and nativism, lead a state to decide not to receive the Code as it was, and instead arrive at its own liberalising compromises. Another example is our analysis of how nativism when combined with anti-French sentiment could overcome the reforming tendencies of a liberal ruler and even of merchant self-interest, bringing about the eventual abandonment of the Code, as happened in the Hanseatic departments. If, on the other hand, anti-French sentiment was weaker and proto-industrial interests stronger, the result was the retention of the Code, as happened in the Rhineland and Berg. Our analysis thus captures the deeper interactions between different social, economic and political circumstances, and provided an explanation as to why these factors had the influence they did, and worked in the combinations they did, in relation to the decision to receive the Code.

As we suggested in the introduction, our findings also have implications for the modern-day debate concerning the legal origins effect. Our findings show that far from being viewed as adverse to private property or contract, the Code was seen as being friendly to them, and its main proponents were not the propertied or feudal

109. FC Schneid Napoleon's Conquest of Europe: The War of the Third Coalition (Westport: Greenwood Publishing Group, 2005) p 118. 
classes, but the merchant classes - exactly the opposite of what legal origins theory would lead us to believe. Nor were judges and lawyers uniformly opposed to the Code, as one would have expected if the Code were really as restrictive of the powers of judges as the legal origins theorists claim. The Code did indeed restrict the power of judges, but other codes drafted at the time went even further - the ALR went as far as to prohibit legal commentaries altogether. The Code did not, therefore, of itself create a path whose necessary consequence was a general unfriendliness to commerce - if anything, it did the opposite. If there is indeed a legal origins effect, our findings suggest that its causes probably did not lie directly in the Code Napoleon, but must be sought in other institutions that were also received in countries that received the French legal system. ${ }^{110}$ Indeed, it could more generally be asserted that the long history of the Code Napoleon in Germany, which lasted up until 1900 in places such as Baden, Berg and the Rhineland, calls into question the depth of the distinction between French and German legal origins. ${ }^{111}$

Our findings also have implications for the modern-day debate concerning the possibility of a European code of private law. As we have shown, the factors which determined whether the Code Napoleon would be fully implemented in accordance with its spirit were diverse and complex. Yet the one point that comes across quite clearly is that the presence of a liberal, internationalist government or jurists keen on the adoption of the Code is not sufficient to ensure that it will be adopted, nor is its adoption any guarantee of its faithful implementation. The Code's strongest successes - adoption, faithful implementation and retention - occurred in Berg and the Rhine Department, and the conditions prevalent in those states demonstrate the importance of engaging with a wider section of the polity and co-opting them into the project.

In conclusion, we hope that the extent to which our analysis has shed new light on the question of the reception of the Code Napoleon in Germany has demonstrated the power of fsQCA as a tool in comparative law. Fuzzy-set QCA cannot, and does not aim to, take the place of careful and methodical comparative research. Its main utility is, rather, as a tool that helps to uncover complex patterns of factors that might otherwise have eluded the researcher, and which may explain similarities - or differences - amongst different jurisdictions. This means that the technique can potentially be applied to a range of very different situations of interest to comparative lawyers. The fact that our example was taken from legal history reflects our current research interests. The technique itself could have equally been applied to questions such as why the Model Law on Arbitration is interpreted and applied so differently in different states, or why specific rules of law, such as the rule in Rylands $v$ Fletcher,${ }^{112}$ develop so differently in different jurisdictions. We hope this paper has convinced other researchers that it, as a methodology, might also be of relevance and use to their research.

\section{APPENDIX: THE PROCESS OF FSQCA}

Fuzzy-set QCA involves a number of distinct tasks. In practice, these do not constitute truly separate, distinct 'stages' of analysis. Rather, fsQCA is an iterative process, although we discuss each task sequentially for clarity of presentation. This appendix

110. A similar point has been made by scholars critical of the claims of the legal origins theorists. See, eg M Siems 'Legal origins: reconciling law \& finance and comparative law' (2007) 52 McGill Law Review 55.

111. We are grateful to Mathias Siems for this point.

112. (1868) LR 3 HL 330. 
sets out the technical details of our analysis, including the construction and calibration of the fuzzy-sets in our analysis, and the identification of necessary and sufficient conditions for the adoption and retention of the Code Napoleon. The purpose of this appendix is twofold: first, to provide further details of our analysis that are too technical or involved to discuss in the body of the text; and, secondly, to give the interested reader a sense of how fsQCA can be used in comparative law, using our study of the reception of the Code in Germany as an illustration.

\section{Evaluating potential causal conditions and outcomes}

In the first stage of our analysis, we identified the various factors that, singly or in combination with other factors, might be thought to have contributed to, or influenced, the decision to adopt or not adopt (and later the choice to retain) the Code Napoleon. In fsQCA, the existence of each causal condition in a particular case is expressed in terms of the degree of membership in a set. For example, cases were assigned a fuzzy-membership score based on the extent to which they adopted the Code Napoleon and retained the Code Napoleon. A state which adopted and faithfully implemented the original French text or a faithful translation of the Code is considered 'fully in' the set of members of countries adopting the Code Napoleon (represented by a numerical score of 1.0). Conversely, a state which did not consider adoption of the Code or rejected it outright is considered 'fully out' of the set (taking a membership score of 0). Between these extremes of full- and non-membership, a number of intermediate cases were fixed: a state which adopted a modified version of the Code or which implemented the Code partially or creatively would be considered 'more in' (0.75); our cross-over point ('neither out nor in', fuzzy-set score of 0.5) corresponded to instances of states which adopted but did not implement the Code; a state which considered adoption of the code but did not actually adopt it is 'more out than in' (0.25). As this example illustrates, the effective use of fuzzy-set analysis depends on careful calibration of set membership, which distinguishes theoretically relevant and irrelevant variation amongst cases. ${ }^{113}$

Done properly, this is an iterative process, with researchers returning to the causal factors and classificatory criteria initially identified as they progress with the research. For example, our initial list of causal factors combined nativism and anti-French sentiment (respectively, numbers 6 and 7 in the list below) as aspects of one potential causal factor. In the process of collecting the data we needed to assign a fuzzymembership score to various states. However, it became apparent that these had to be treated separately, as the southern states frequently combined a high degree of nativism or local patriotism with a relatively low degree of anti-French sentiment. Similarly, some causal conditions we initially identified - such as attitudes towards women - were abandoned in the course of our analysis as there was no significant variation on this point among the different German states we studied.

The causal factors we identified, together with their justification, were discussed in section 3(a). The benchmarks we developed for identifying the degree of each state's membership both in sets identifying causes and the relevant outcomes of interest are set out in table 1 . Below, we set out the principles based on which we derived the benchmarks, together with a description of the target set of states that satisfy the condition.

113. See further C Ragin Redesigning Social Inquiry: Fuzzy-Sets and Beyond (Chicago: University of Chicago Press, 2008) ch 5. 
1. Territorial diversity: in examining this factor, we were interested in the extent to which the changes brought about by the Napoleonic period had affected the social and legal diversity within the territory of a state. The target set was therefore the set of states with a high degree of social and legal diversity as a result of expansion, and the degree of each state's membership was determined by the extent of social and legal diversity in that state.

2. Control by Napoleon: the target set for this condition was the set of states which were subject to absolute control or subjugation by Napoleon. The degree of membership depended, therefore, in part on the extent to which the threat of control was a real one, but also in part on the extent to which a state voluntarily hitched itself to Napoleon in the hope of benefitting from, for example, future distribution of territory. One aspect of this - the threat of direct intervention or assumption of control - was particularly strong in the small states which had survived mediatisation and resulted in them being given higher scores than their situation would otherwise lead one to expect. Equally, in some states, the threat of Napoleonic control was notable by its absence - if, for example, Napoleon could not afford to antagonise a state whose support he needed, as appears to have been the case with Saxony.

3. Institutional strength: our aim in assessing this condition was to evaluate the extent to which a state had strong central institutions of its own and hence potentially a lesser need for receiving French instituions. The target set for this condition was therefore the set of states which had strong central institutions of governance. The degree of a state's membership in the set depended on whether any central institutions existed, and the extent to which they permeated the entirety of a state's territories.

4. Feudalism: in evaluating this factor, we were interested in the extent to which the economy of the states we studied was traditionally feudal, as opposed to modern, and also in the extent to which this was reflected in the concerns of the governing class. We therefore looked not only at the economy but also at the relationship between the feudal or mercantile elites and the state and its institutions. In the process, we also took account of variations within feudal systems by, for example, giving a state following the Gutsherrschaft system a higher score than a state following the Grundherrschaft system, and of variations within mercantile economies by assigning a higher score for the presence of sectors that demonstrated proto-industrialisation.

5. Liberalism: the target set for this condition was the set of states which adopted liberal policies. In assessing this factor, we focused principally on reforms other than land reforms, to avoid capturing the same factor - the strength of the feudal class - twice. The state's degree of membership depended principally upon the policies actually adopted by the state, but it was also influenced by the manner in which a state reacted to liberal groups within the populace. A conservative state which actively sought to suppress liberals, as Württemberg did, obtained a lower score than a conservative state which tolerated their presence.

6. Nativist ideology: our aim in looking at this condition was to assess the impact which a localist or nativist orientation in state policy - or, more broadly, 'local patriotism' amongst the governing classes - had upon the decision to adopt or retain the Code. The target set was, respectively, the set of states whose governments were strongly nativist.

7. Anti-French sentiment: our aim in looking at this condition was to assess the impact which anti-French public sentiment had upon the decision to adopt or retain the Code. The target set was the set of states whose polities were strongly Francophobic and the degree of membership in the set was defined by the extent to which anti-French sentiments were manifest in public action. 
8. Adoption: the outcome with which our study was concerned was the decision to adopt the Code. As discussed in the introduction, the extent of adoption of the Code varied considerably across different states, ranging from adoption of the original French text or a faithful translation to a refusal to even consider the adoption of the Code. In addition, amongst states who adopted the code, the extent of implementation varied, with some states applying it in ways that deviated significantly from what the Code was intended to accomplish. In assessing this outcome, therefore, our target set is the set of states who adopted and faithfully implemented the Code Napoleon in accordance with its letter and spirit. We also examined the decision to retain the Code after the fall of Napoleon, though we did not undertake a separate analysis of this because of the extremely limited number of cases involved.

\section{Assessing the factors}

The aim of this process is to evaluate the degree of membership of each state in the set of countries in which a particular condition was present, and the outcome is a membership score on a scale of $0-1$ which was as noted above assigned with reference to the benchmarks set out in Table 1. As with the process of calibration described above, this step involves an element of judgement: fsQCA does not aim to reduce or eliminate the role of the researcher's informed, scholarly judgement, but rather to provide tools that assist the researcher in exercising that judgement in a more structured way than in a non-formal comparison of cases. Fuzzy-set scores for all of the causal conditions and both outcome measures in our analysis are set out in Table 2.

There is a wide range of legal and historical literature on conditions in preNapoleonic and Napoleonic Germany. The sources cited in section 3 are representative of the type and range of the sources we used in our assessment of the degree of each state's membership in the set of each of the various potential causal conditions we analyse. Three sources which stand out for special mention are Blackenburg's doctoral dissertation from 1931 on the adoption of the Code Civil in Germany, ${ }^{114}$ Fehrenbach's 1974 study of the debate surrounding the adoption of the Code in the Rheinbund ${ }^{115}$ and Werner Schubert's Habilitationsschrift on the reception of French law in Germany, published in revised form in 1977. ${ }^{116}$

After gathering together the relevant material for each condition and each state, we assessed the extent of a state's membership in a set by first identifying the closest benchmark, and then adjusting the state's membership score for that conditon up or down, depending on the nature and strength of the factors that diverged from the benchmark. Table 2 presents the results of our assessment for all 14 states in relation to the seven conditions and the single outcome that are the subject of our study.

This process, too, is iterative, with researchers returning to consider whether the combinations of causal factors and outcomes contained in the table contain sufficient variation for the purpose of analysis and, if not, to revisit their choice of cases. Questions a researcher might ask include whether the selected cases present a sufficiently wide range of variation on the $0-1$ scale used in fsQCA in relation to potential

114. Blackenburg, above $\mathrm{n} 4$.

115. E Fehrenbach Traditionale Gesellschaft und revolutionares Recht: die Einführung des Code Napoleon in den Rheinbundstaaten Kritische Studien zur Geschichtswissenschaft, bd. 13 (Gottingen: Vandenhoeck \& Ruprecht, 1974).

116. Schubert, above $\mathrm{n} 21$. 


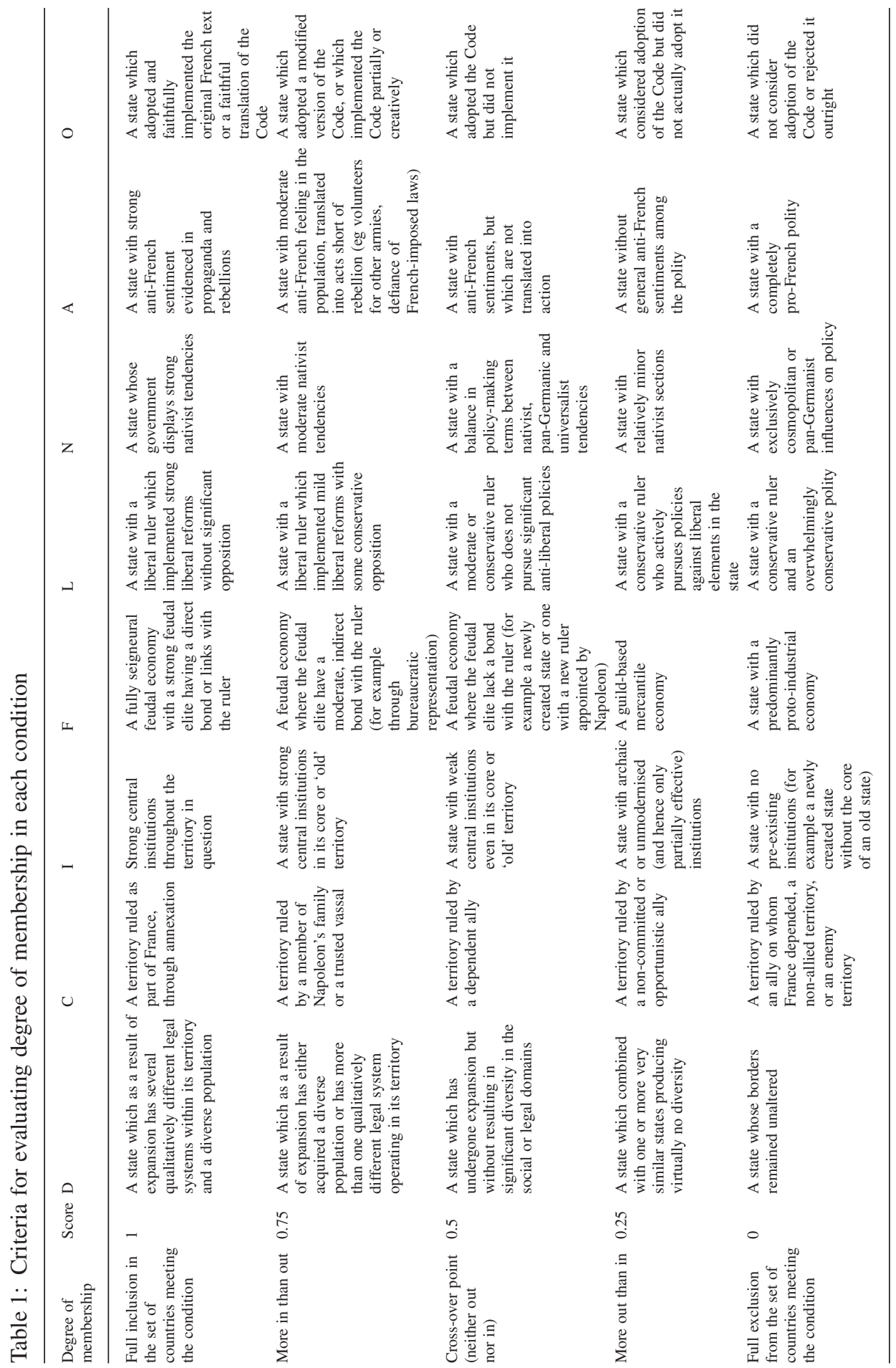


Table 2: Potential causes of the acceptance or rejection of the Code Napoleon

\begin{tabular}{lllllllll}
\hline State & $\mathrm{D}$ & $\mathrm{C}$ & $\mathrm{F}$ & $\mathrm{I}$ & $\mathrm{L}$ & $\mathrm{N}$ & $\mathrm{A}$ & $\mathrm{O}$ \\
\hline Rhine departments & 1 & 1 & 0.4 & 0 & 0.5 & 0 & 0.5 & 1 \\
Kingdom of Westphalia & 1 & 0.75 & 0.6 & 0 & 0.6 & 0 & 0.9 & 1 \\
Grand Duchy of Berg & 1 & 0.75 & 0.4 & 0 & 0.75 & 0 & 1 & 1 \\
Grand Duchy of Baden & 1 & 0.35 & 0.7 & 0.8 & 1 & 1 & 0.4 & 0.65 \\
Grand Duchy of Frankfurt & 0.6 & 0.75 & 0.3 & 0 & 0.9 & 0 & 0.75 & 0.75 \\
Duchy of Ahremberg & 0.75 & 0.7 & 0.5 & 0 & 0.5 & 0.1 & 0.3 & 1 \\
Duchy of Anhalt-Köthen & 0 & 0.65 & 0.4 & 1 & 0.5 & 0.6 & 0.5 & 0.6 \\
Hanseatic departments & 0.25 & 1 & 0.3 & 0.75 & 0.5 & 0 & 0.8 & 1 \\
Duchy of Nassau & 0.6 & 0.25 & 0.6 & 0.9 & 1 & 0.5 & 0.5 & 0.5 \\
Hesse-Darmstadt & 0.7 & 0.30 & 0.5 & 0.75 & 0.75 & 0.75 & 0.5 & 0.4 \\
Grand Duchy of Würzburg & 0.3 & 0.6 & 0.4 & 0.25 & 0.5 & 0.25 & 0.3 & 0.5 \\
Bavaria & 0.6 & 0.25 & 0.9 & 0.75 & 1 & 1 & 0.4 & 0.25 \\
Saxony & 0.4 & 0 & 0.8 & 0.75 & 0.4 & 1 & 1 & 0 \\
Württemberg & 0.8 & 0 & 1 & 0.8 & 0 & 0.8 & 0.6 & 0 \\
\hline
\end{tabular}

causal factors and outcomes (and do not, for example, omit values at the high or low end of the range for any of these conditions), and whether any theoretically important combination of factors and outcomes that actually occured in relation to the problem being studied remains unobserved. A failure to address these questions properly can produce systematic error and it is important that researchers identify potential problems in relation to the set of cases they have chosen. Close inspection of the table of conditions and outcomes is helpful in this respect. In analyses involving a small number of cases and more than a very small number of causal conditions, inevitably a large number of potential combinations of conditions will remain unobserved, but researchers can still engage with this process to understand the limitations of their choice of cases and to re-examine whether the criteria they used to select the cases they chose are the most appropriate to the particular topic they propose to research. For example, an examination of our initial coding led us to conclude that our sample was skewed in several ways, which we corrected by adding further cases - notably Würzburg and Saxony - to the set of cases we proposed to analyse.

\section{Reducing causal complexity}

The third task of fsQCA is to identify the combinations of factors that produce the outcomes of interest, namely the adoption and retention of the Code Napoleon. In this task, we are supported by the use of QCA software. All the analyses in this paper were performed on fs/QCA 2.5, developed by Charles Ragin, Kriss Drass and Sean Davey. ${ }^{117}$

The first step is to produce a 'truth table', or a table of configurations of cases as shown in Table 3 . Note that Table 3 shows only the combinations actually present in the data: many more counter-factual combinations exist - for seven causal conditions,

117. The software, fs/QCA, is available as a free download from Charles Ragin's web pages on the University of Arizona website, available at http://www.u.arizona.edu/ cragin/fsQCA/ software.shtml. 
Table 3: Truth table representation of factors in adoption of the Code

\begin{tabular}{llllllllll}
\hline C & D & F & I & L & N & A & Number & Consistency & Adoption \\
\hline 1 & 1 & 1 & 0 & 1 & 0 & 1 & 1 & 1.00 & 1 \\
1 & 1 & 0 & 0 & 1 & 0 & 1 & 2 & 1.00 & 1 \\
0 & 1 & 1 & 1 & 1 & 1 & 0 & 2 & 0.82 & 1 \\
0 & 0 & 1 & 1 & 0 & 1 & 1 & 1 & 0.52 & 0 \\
0 & 1 & 1 & 1 & 0 & 1 & 1 & 1 & 0.33 & 0 \\
\hline
\end{tabular}

Table 4: Complex solution for adoption of Code Napoleon

\begin{tabular}{lllll}
\hline Solution & Cases & $\begin{array}{l}\text { Raw } \\
\text { coverage }\end{array}$ & $\begin{array}{l}\text { Unique } \\
\text { coverage }\end{array}$ & Consistency \\
\hline $\mathrm{c} * \mathrm{~d} * \sim \mathrm{i} * \mathrm{l} * \sim \mathrm{n} * \mathrm{a}$ & Berg, Frankfurt, Westphalia & 0.439 & 0.370 & 1.000 \\
$\sim \mathrm{c} * \mathrm{~d} * \mathrm{f} * \mathrm{i} * 1 * \mathrm{n} * \sim \mathrm{a}$ & Baden, Bavaria & 0.231 & 0.162 & 0.816 \\
Solution coverage: & 0.601 & & & \\
Solution consistency: & 0.921 & & & \\
\hline
\end{tabular}

$2^{7}$ or 128 potential combinations exist, far more than the number of German states at the time. Only a few of these - five configurations in all - were in fact represented within our selection of cases.

The truth table algorithm in fsQCA is used to solve the truth table, in order to identify simplified solutions (combinations of conditions) that adequately explain the outcome of interest. This is done by reducing more complex expressions (combinations of conditions) to less complex combinations of conditions using the containment rule. ${ }^{118}$

Three types of solution are obtained in fsQCA: a 'complex solution', a 'parsimonious solution' and an 'intermediate solution'. The difference lies in the simplifying assumptions made about the cases not observed. In the complex solution, no such simplifying assumptions are made, while the parsimonious solution makes whatever counter-factual assumptions are necessary to produce the simplest solution. For the intermediate solution, the researcher evaluates the plausibility of the simplifying assumptions, allowing only 'easy' counterfactuals, that is, those that are well supported by the researcher's substantive and theoretical knowledge. ${ }^{119}$

Looking first at the complex solution reported in Table 4, the analysis shows two causal combinations linked to adoption of the Code Napoleon. The first combination, instanced by the cases of Berg, Frankfurt and Westphalia, shows the following causal relation:

$$
\mathrm{c} * \mathrm{~d} * \sim \mathrm{i} * 1 * \sim \mathrm{n} * \mathrm{a} \rightarrow \text { adoption }
$$

That is to say, adoption of the Code Napoleon occurred where the following conditions were satisfied: control by Napoleon, territorial diversity, absence of strong institutions, liberalism, absence of nativism and anti-French sentiment. This last

118. Ragin, above n 29, pp 107-115.

119. See Ragin, above $\mathrm{n} 113$, ch 9 for further details. 
condition, anti-French sentiment, may appear surprising, but the presence of a condition in the complex solution does not necessarily imply causation. This is discussed when we contemplate the intermediate solution below.

The second combination, instanced in Baden and Bavaria, is represented by the relation:

$$
\sim \mathrm{c} * \mathrm{~d} * \mathrm{f} * \mathrm{i} * 1 * \mathrm{n} * \sim \mathrm{a} \rightarrow \text { adoption }
$$

This means the following combination of conditions also led to codification: the absence of control by Napoleon, territorial diversity, feudalism, strong institutions, nativism and the absence of anti-French sentiment. Note that both $\mathrm{d}$ and 1 belong to both solutions, indicating that these are both necessary (but not sufficient) conditions, but that these two conditions, in the presence of more than one combination of other conditions, indicate codification.

The values reported as 'solution consistency' and 'solution coverage' offer a means of assessing the degree of fit of the solution with the fuzzy-set scores for each condition. ${ }^{120}$ Briefly, consistency is the extent to which the posited set-theoretical relation holds up against the data, while coverage is the extent to which an outcome is accounted for in the the solution. Thus, the solution coverage of 0.901 indicates a very good degree of consistency with the posited solution, though falling short of perfect consistency. Similarly, the final column of Table 4 shows the consistency of each combination in the solution. The first solution shows perfect consistency, taking a value of 1.000 , while the second had a slightly lower level of consistency of 0.816 .

In terms of coverage, our complex solution had a solution coverage of 0.601 , indicating that the posited causal conditions account for just over $60 \%$ of the outcome values. Again, Table 4 breaks down coverage to give separate values for each combination, although, this time, two separate measures are given. Briefly, 'raw coverage' is the total coverage of each solution, while 'unique coverage' indicates only the additional coverage provided over and beyond the second solution. This gives a way of assessing the empirical importance of each path: the fact that the sum of the unique coverage of each path of conditions provided is slightly higher than the first path indicates that the two-path model has a modest empirical importance over and beyond the understanding contributed by a solution consisting only of a single path.

Turning to the intermediate solution, we assumed that the following conditions were contributed causally to the adoption of the Code (the justification for these assumptions can be found in the discussion in section 3):

- territorial diversity;

- Napoleonic control;

- weak institutions;

- the absence of anti-French sentiment;

- the absence of nativism.

The intermediate solution is presented in Table 5, below. Compared with the complex solution, the first combination in the intermediate solution shows the slightly simpler causal relation:

$$
\mathrm{c} * \mathrm{~d} * \sim \mathrm{i} * 1 * \sim \mathrm{n} \rightarrow \text { adoption }
$$

The difference is that anti-French sentiment has been eliminated. This accords with the intuition, above, that anti-French sentiment may have been an effect rather than a

120. See ibid, ch 3 for further details. 
Table 5: Intermediate solution for adoption of Code Napoleon

\begin{tabular}{lllll}
\hline Solution & Cases & $\begin{array}{l}\text { Raw } \\
\text { coverage }\end{array}$ & $\begin{array}{l}\text { Unique } \\
\text { coverage }\end{array}$ & Consistency \\
\hline $\mathrm{c}^{*} \mathrm{~d} * \sim \mathrm{i} * 1 * \sim \mathrm{n}$ & Berg, Frankfurt, Westphalia & 0.462 & 0.208 & 1.000 \\
$\mathrm{~d} * 1 * \mathrm{f} * \sim \mathrm{a}$ & Baden, Bavaria & 0.416 & 0.161 & 0.889 \\
Solution coverage: & 0.624 & & & \\
Solution consistency: & 0.923 & & & \\
\hline
\end{tabular}

Table 6: Parsimonious solution for adoption of Code Napoleon

\begin{tabular}{lllll}
\hline Solution & Cases & $\begin{array}{l}\text { Raw } \\
\text { coverage }\end{array}$ & $\begin{array}{l}\text { Unique } \\
\text { coverage }\end{array}$ & Consistency \\
\hline 1 & $\begin{array}{l}\text { Baden, Nassau, Bavaria, } \\
\text { Frankfurt, Berg, } \\
\text { Hesse-Darmstadt, }\end{array}$ & 0.740 & 0.740 & 0.719 \\
& Westphalia & & \\
& 0.740 & & \\
Solution coverage: & 0.719 & & \\
Solution consistency: & & & \\
\hline
\end{tabular}

cause of codification in countries with a high degree of Napoleonic control. The second combination is represented by the relation:

$$
\mathrm{d} * \mathrm{f} * 1 * \sim \mathrm{a} \rightarrow \text { adoption }
$$

This means the following combination of conditions also led to codification: territorial diversity, feudalism, nativism and the absence of anti-French sentiment. The conditions $\sim \mathrm{c}, \mathrm{i}$ and $\mathrm{n}$ are thus eliminated from the second pathway as a result of the simplifying assumptions adopted in the intermediate solution. The use of simplifying solutions makes a very modest (positive) difference to the solution coverage and solution consistency, compared with the complex solution. If our assumptions were contra-indicated by the data, we would have expected to see a lower degree of consistency.

Finally, the parsimonious solution, shown in Table 6 gives a unique solution involving one single condition: liberalism. Too much reliance should not be placed on the parsimonious solution, however: the consistency of the solution of 0.719 suggests a poor fit with the data. More importantly, perhaps, this solution involves a number of assumptions about the hypothetical outcomes in counter-factual cases that are not plausible from the point of view of theory.

Having analysed the conditions for the adoption of the Code Napoleon, we can similarly analyse the conditions for non-adoption. The complex solution is shown in Table 7; the intermediate solution is found in Table 8. We assumed that strong membership in the following conditions was likely to contribute to non-adoption of the code:

- absence of Napoleonic control;

- strong institutions;

- anti-French sentiment;

- nativism. 
Table 7: Complex solution for non-adoption of Code Napoleon

\begin{tabular}{lllll}
\hline Solution & Cases & $\begin{array}{l}\text { Raw } \\
\text { coverage }\end{array}$ & $\begin{array}{l}\text { Unique } \\
\text { coverage }\end{array}$ & Consistency \\
\hline$\sim \mathrm{c} * \mathrm{f} * \mathrm{i} * \sim 1 * \mathrm{n} * \mathrm{a}$ & Saxony, Württemberg & 0.383 & 0.290 & 1.000 \\
$\sim \mathrm{c} * \mathrm{~d} * \mathrm{f} * \mathrm{i} * 1 * \mathrm{n} * \sim \mathrm{a}$ & Baden, Bavaria & 0.411 & 0.318 & 0.898 \\
Solution coverage: & 0.700 & & & \\
Solution consistency: & 0.938 & & & \\
\hline
\end{tabular}

Table 8: Intermediate solution for non-adoption of Code Napoleon

\begin{tabular}{lllll}
\hline Solution & Cases & $\begin{array}{l}\text { Raw } \\
\text { coverage }\end{array}$ & $\begin{array}{l}\text { Unique } \\
\text { coverage }\end{array}$ & Consistency \\
\hline$\sim \mathrm{c} * \mathrm{f} * \mathrm{i} * \sim 1 * \mathrm{n} * \mathrm{a}$ & Saxony, Württemberg & 0.383 & 0.215 & 1.000 \\
$\sim \mathrm{c} * \mathrm{~d} * \mathrm{f} * \mathrm{i} * 1 * \mathrm{n}$ & Baden, Bavaria & 0.486 & 0.317 & 0.897 \\
Solution coverage: & 0.700 & & & \\
Solution consistency: & 0.926 & & & \\
\hline
\end{tabular}

The first path for both the complex and the intermediate solution is:

$$
\sim \mathrm{c} * \mathrm{f} * \mathrm{i} * \sim \mathrm{l} * \mathrm{n} * \mathrm{a} \rightarrow \text { non-adoption }
$$

The second pathway in the complex solution is:

$$
\sim \mathrm{c} * \mathrm{~d} * \mathrm{f} * \mathrm{i} * 1 * \mathrm{n} * \sim \mathrm{a} \rightarrow \text { non-adoption }
$$

While in the intermediate solution, the absence of anti-French sentiment is eliminating, giving:

$$
\sim \mathrm{c} * \mathrm{~d} * \mathrm{f} * \mathrm{i} * \mathrm{l} * \mathrm{n} \rightarrow \text { non-adoption }
$$

In other words, the absence of Napoleonic control, feudalism, strong institutions and nativism are necessary but not sufficient conditions for non-adoption of the code. In addition to these factors, either the absence of liberalism and anti-French sentiment or liberalism and territorial diversity were necessary conditions for the non-adoption of the Code.

The parsimonious solution for non-adoption of the Code is shown in Table 9. The solution suggests three pathways, each involving a single condition, respectively: the absence of Napoleonic control, strong institutions and nativism. The consistency of the set-theoretic relationship in this solution is unacceptably poor, and, again, involves the making of implausible counter-factual assumptions.

The consistency for non-adoption was similar to solutions for adoption of the Code, in each case greater than 0.9 both for the complex and intermediate solutions, while there is consistently better coverage: 0.7 for both complex and intermediate solutions, compared with around 0.6 for the adoption of the Code. Again, there is no substantial drop-off in consistency, suggesting that our simplifying assumptions are not unwarranted. 
Table 9: Parsimonious solution for non-adoption of Code Napoleon

\begin{tabular}{|c|c|c|c|c|}
\hline Solution & Cases & $\begin{array}{l}\text { Raw } \\
\text { coverage }\end{array}$ & $\begin{array}{l}\text { Unique } \\
\text { coverage }\end{array}$ & Consistency \\
\hline$\sim \mathrm{c}$ & $\begin{array}{l}\text { Saxony, Württemberg, } \\
\text { Nassau, Bavaria, } \\
\text { Hesse-Darmstadt, } \\
\text { Baden }\end{array}$ & 0.972 & 0.112 & 0.782 \\
\hline $\mathrm{i}$ & $\begin{array}{l}\text { Anhalt-Köthen, Nassau, } \\
\text { Baden, Württemberg, } \\
\text { Hans, Hesse-Darmstadt, } \\
\text { Bavaria, Saxony }\end{array}$ & 0.822 & -0.000 & 0.652 \\
\hline $\mathrm{n}$ & $\begin{array}{l}\text { Baden, Bavaria, Saxony, } \\
\text { Württemberg, } \\
\text { Hesse-Darmstadt, } \\
\text { Anhalt-Köthen }\end{array}$ & 0.869 & -0.000 & 0.775 \\
\hline Solution coverage: & 0.981 & & & \\
\hline Solution consistency: & 0.593 & & & \\
\hline
\end{tabular}

\section{Interpreting the results}

The fourth stage of fsQCA involves interpreting the results of the third stage. Fuzzyset QCA suggests an empirical connection between the presence and strength of various potential causal conditions, singly or in combination, and a specified outcome. It does not (and cannot) indicate causation or explain why these conditions produce the outcome they do. Such questions can only be answered with the help of the researcher's substantive and theoretical knowledge. We presented our analysis in section 3.

In a sense, this stage is the most important aspect of the analysis, as the researcher tries to understand the implications of the possible causal configurations which the third stage throws up. As an example of how this process works, we offer our analysis of the impact of liberalism. As tables 5 and 6 show, the results of fsQCA suggested that liberalism was causally linked both with the decision to adopt the Code and with the decision not to adopt the Code. This result at first seems counter-intuitive, but a closer examination of the surrounding circumstances in specific cases which produced these results - in other words, of the German states where liberalism led to a decision to adopt the Code, and those where liberalism led to a decision not to adopt the Code - showed a deeper and more interesting pattern: that states where liberalism was especially strong tended not to adopt the Code, particularly if nativism was also present and strong, whereas states which were less staunchly liberal were more likely to adopt the Code. This led us to the findings we presented in section 3(b) - findings which are important, but which would most likely have been overlooked in a more conventional comparative analysis. 